\title{
Desensitization of the Insulin Receptor by Antireceptor Antibodies In Vivo is Blocked by Treatment of Mice with $\beta$-Adrenergic Agonists
}

\author{
Dana Elias, "* Micha Rapoport, Irun R. Cohen, ${ }^{\ddagger}$ and Yoram Shechter* \\ Departments of ${ }^{*}$ Hormone Research and ${ }^{\ddagger}$ Cellular Biology, The Weizmann Institute of Science, Rehovot 76100, Israel; \\ and ${ }^{\S}$ Department of Internal Medicine B, Asaf Harofeh Hospital, Zerifin, Israel
}

\begin{abstract}
In previous studies we reported that immunization of mice with ungulate insulins induced the development of antiinsulin antibodies, which include an idiotype that appeared to recognize the part of the insulin molecule recognized by the hormone receptor. The antiinsulin antibodies of this idiotype were replaced spontaneously by antiidiotypic antibodies. The antiidiotypic antibodies, which persisted for about $14 \mathrm{~d}$, mimicked insulin and functioned as antibodies to the insulin receptor. They induced down regulation, desensitization and refractoriness of the insulin receptor and disturbances in glucose homeostasis in vivo (Shechter, Y., D. Elias, R. Maron, and I. R. Cohen., 1984; Elias, D., R. Maron, I. R. Cohen, and Y. Shechter. 1984, J. Biol. Chem. 259:6411-6419). We now report that effects of the antiidiotypic antibodies on the insulin receptor effector system can be modified pharmacologically. Administration of the $\beta$-adrenergic agonist isoproterenol during the period of insulin resistance (days 26-40 after primary immunization), largely restored fat cell responsiveness to insulin, and eliminated the appearance of fasting hyperglycemia. This restoration appeared to be caused by inhibition of both insulin receptor desensitization and refractoriness. In contrast, down regulation of insulin receptors was not reversed by isoproterenol treatment in vivo. The effects of treatment with isoproterenol persisted for $2-4 \mathrm{~d}$ after termination of treatment. The $\beta$-antagonist, propranolol and more so, the $\beta_{1 \mathrm{a}}$-antagonist metoprolol, specifically blocked the effect of isoproterenol at a molar ratio of 3-10:1. Oral administration of the cAMP phosphodiesterase inhibitor, aminophylline, was also effective in inhibiting the development of desensitization in fat cells. These results indicate that treatment with $\beta_{1}$-adrenergic agonists in vivo, or other agents that elevate cellular cAMP levels, can inhibit the development of the "postbinding" defects induced by insulin-mimicking, antireceptor antibodies. These observations have both basic and clinical implications.
\end{abstract}

\section{Introduction}

High concentrations of insulin were shown to decrease the number of insulin receptors (down regulation) in both in vivo and in vitro systems (1-5). Down regulation has been demon-

Address reprint requests to Dr. Shechter, Department of Hormone Research, The Weizmann Institute of Science, Rehovot 76100, Israel.

Received for publication 17 August 1987 and in revised form 22 December 1987.

J. Clin. Invest.

(c) The American Society for Clinical Investigation, Inc.

0021-9738/88/06/1979/07 \$2.00

Volume 81, June 1988, 1979-1985 strated in several types of insulin-responsive cells, including rat adipocytes (6-13). The decrease in insulin binding capacity was $\sim 50-60 \%$ and occurred half-maximally within $2-3 \mathrm{~h}$ at $37^{\circ} \mathrm{C}$ at high concentrations of insulin (reviewed in 14). Receptor loss is primarily the consequence of an accelerated rate of receptor degradation, as the rate of receptor biosynthesis remained unaltered (14). Hyperinsulinemia was also shown to induce refractoriness in target tissues (defined as a decrease in the maximal biological effect) and desensitization (defined as a shift to the right in the dose response curve to insulin). Refractoriness was observed in rat adipocytes (10) and desensitization was observed both in fibroblasts (15) and in hepatoma cells (16). Although down regulation, refractoriness, and desensitization may be induced by common factors, they most likely are caused by different mechanisms. Hepatoma cells after a limited exposure to insulin in vitro recovered fully their ability to respond again to insulin within $2 \mathrm{~h}$, while recovery of their insulin binding capacity required $\sim 24 \mathrm{~h}$ (16). Thus, desensitization is not caused by down regulation, but must involve a postreceptor mechanism. The possible connection between these processes and insulin resistance in human diabetes $(1,2,4)$ makes their study clinically important.

In previous studies we observed that immunization of mice with ungulate insulins induced the development, first of insulin antibodies, and then of antiidiotypic antibodies that recognized and interacted with the insulin receptor, and mimicked the actions of insulin in vitro (17-20). This insulin-like antireceptor antibody was of the IgG2 class and its circulating level was equivalent functionally to $\sim 200 \mathrm{ng} / \mathrm{ml}$ insulin $(17,18$, 20). The appearance of antireceptor antibody was transitory; starting on day 26 after the primary immunization and persisting for about $14 \mathrm{~d} \mathrm{(18)}$. The presence of circulating antireceptor antibodies induced tissue alterations in the mice in vivo. The adipocytes of antibody positive mice exhibited lower responsiveness to insulin as a consequence of receptor down regulation, refractoriness, and desensitization (18). Marked disturbances in glucose homeostasis were evident; a period of fasting hypoglycemia was initially observed to be replaced by fasting hyperglycemia when insulin resistance developed (18). Thus, in addition to what these mice can teach us about insulin autoimmunity and antiidiotypic networks, they provide a convenient in vivo experimental system of insulin resistance that may be analogous, at least in part, to the insulin resistance developing in humans as a consequence of fluctuations in the circulating levels of insulin and glucose (1).

As the mechanism(s) of action of insulin are largely unknown, in particular the events linking the activated receptor to the expression of biological processes (reviewed in 14, 21, 22 ), it is not currently possible to specify the molecular mechanism responsible for insulin resistance. It is known, however, that hormones and agents that elevate cellular cAMP levels (e.g., catecholamines, glucagon and cAMP-phosphodiesterase 
[PDE] inhibitors) have an antagonistic influence on several insulin-responsive cellular enzyme systems (23-30). As desensitization, down regulation, and refractoriness are insulin-dependent cellular events, we reasoned that factors which elevate cellular cAMP levels may also antagonize the development of insulin resistance in vivo.

Here, we report that administration of either isoproterenol or aminophylline to immunized mice blocks the development of fat cell desensitization and refractoriness to insulin, but does not prevent insulin receptor down regulation.

\section{Methods}

Materials. Male mice of the $(\mathrm{BALB} / \mathrm{c} \times \mathrm{C} 57 \mathrm{BL} / 6) \mathrm{F}_{1}$ hybrid strain and male Wistar rats $(70-100 \mathrm{~g}$ ) were supplied by the animal breeding center of this Institute or by Jackson Laboratories, Bar Harbor, ME. Bovine insulin and isoproterenol were purchased from Sigma Chemical Co. (St. Louis, MO), and porcine insulin from Eli-Lilly \& Co. (Indianapolis, IN). D[U- $\left.{ }^{14} \mathrm{C}\right]$ Glucose $(4-7 \mathrm{mCi} / \mathrm{mol})$ was purchased from New England Nuclear (Boston, MA). Collagenase type I (134 $\mathrm{U} / \mathrm{mg}$ ) was from Worthington Biochemicals (Freehold, NJ) and Sepharose-protein A affinity columns from Pharmacia Fine Chemicals, Uppsala, Sweden.

Procedures. Mice were immunized by injecting each hind footpad with $25 \mu \mathrm{g}$ of bovine insulin emulsified in complete Freund's adjuvant, as described (19). Control mice were immunized with the adjuvant alone. Unless otherwise mentioned a single immunization protocol was used. Isoproterenol ( $30 \mu \mathrm{g} /$ mouse, i.p.) or other catecholamines, as specified in the specific experiments, were administered twice a day, for a period of either 7 or $15 \mathrm{~d}$; at 8 a.m. and 3 p.m., starting on day 26 after immunization. Aminophylline ( $1 \mathrm{mg} / \mathrm{d}$ per mouse) was administered orally. Every $2 \mathrm{~d}$ several mice were killed and adipocytes were prepared for determination of their responsiveness to insulin and their insulin binding capacity. Blood was collected for determination of the levels of antiinsulin and antireceptor antibodies as described (17-19).

The following methods and procedures were used without modification: Preparation of mouse or rat adipocytes from epididymal fat pads (31); iodination of insulin (32); binding of [ $\left.{ }^{125} \mathrm{I}\right]$ iodoinsulin to adipocytes (33); assay of lipogenesis (34); and solid phase radioimmunoassay for measuring antibodies to insulin (35). Glucose was determined in individual sera using a glucose analyzer (type II; Beckman Instruments, Inc., Fullerton, CA) and expressed as $\mathrm{mg} / 100 \mathrm{ml}$ of glucose in the serum.

Percent maximal stimulation of lipogenesis was calculated using the equation $V_{\text {ins }}-V_{\text {basal }} / V_{\max }-V_{\text {basal }} \times 100$, where $V_{\text {ins }}, V_{\text {basal }}$, and $V_{\max }$ are the rates of lipogenesis at a given insulin concentration, either in the absence of insulin or at an insulin concentration of $100 \mathrm{ng} \mathrm{ml}^{-1}$, respectively.

$\mathrm{ED}_{50}$ values were derived from the corresponding figures. The results shown in the tables and figures were confirmed by repeating each of the experiments at least three times with similar results. Student's $t$ test analysis of the differences between groups showed them to be highly significant $(P<0.01)$.

\section{Results}

Isoproterenol prevents fat cell desensitization. In previous studies, we learned that antireceptor antibodies are first detected in the circulation $26 \mathrm{~d}$ after immunization. They remain high for 12-14 $\mathrm{d}$ and then decline to undetectable levels (18). Therefore, we administered a catecholamine agonist daily from day 26 to day 40 after immunization; the period in which receptor antibodies were present and insulin resistance was developing. Isoproterenol was chosen because of its potency as a $\beta$-adrenergic agonist (36). Fat tissue has been shown to be primarily of

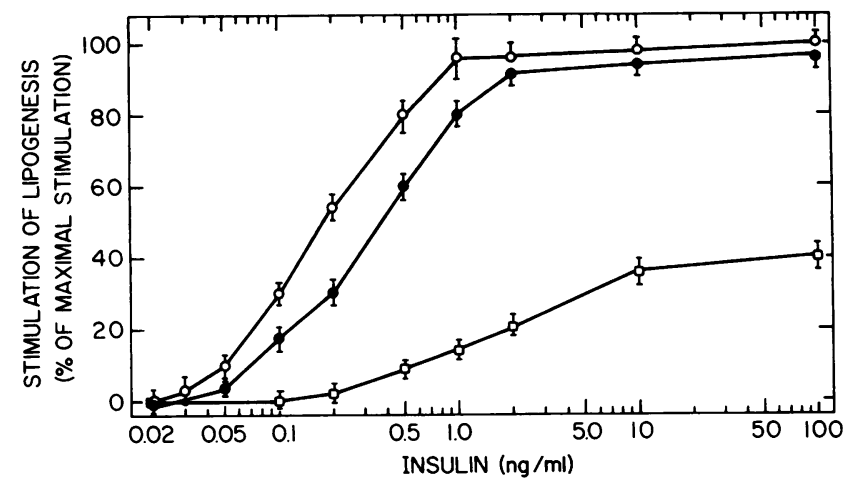

Figure 1. Administration of isoproterenol prevents desensitization of insulin receptors in immunized mice. The lipogenic response to insulin was measured using adipocytes obtained from control mice (that received isoproterenol) ( 0 ), from mice that were immunized to insulin (), and from insulin-immunized mice that received isoproterenol (๑). Each group contained adipocytes pooled from five mice. Adipocytes were measured for their responsiveness to insulin $36 \mathrm{~d}$ after immunization. Isoproterenol was administered twice daily (30 $\mu \mathrm{g} / \mathrm{d})$, starting on day 26 after immunization to insulin. Results are means $\pm S D$ of a representative experiment. Maximal (100\%) stimulation was assigned to the maximal $V_{\text {ins }}-V_{\text {basal }}$ of the control group.

$\beta 1$-subtype-responsive tissue (37). Groups of mice were sacrificed and the lipogenic activity of their adipocytes determined at increasing concentrations of insulin. One group of immunized mice received PBS only, while another group of nonimmunized mice received isoproterenol. Fig. 1 shows that treatment with isoproterenol prevented the development of resistance to insulin. For example, the adipocytes of control mice showed an $E_{50}$ of $0.15 \pm 0.02 \mathrm{ng} / \mathrm{ml}$ while those of immunized mice showed an $\mathrm{ED}_{50}$ of $1.9 \pm 0.2 \mathrm{ng} / \mathrm{ml}$. Treatment of immunized mice with isoproterenol restored the $\mathrm{ED}_{50}$ to $0.35 \pm 0.01$ $\mathrm{ng} / \mathrm{ml}$ (derived from Fig. 1). In other experiments we found that treating control mice with isoproterenol did not affect the dose response to insulin ( $E_{50}$ and maximal response) compared with mice treated with PBS (not shown). The protective effect of isoproterenol in inhibiting fat-cell desensitization

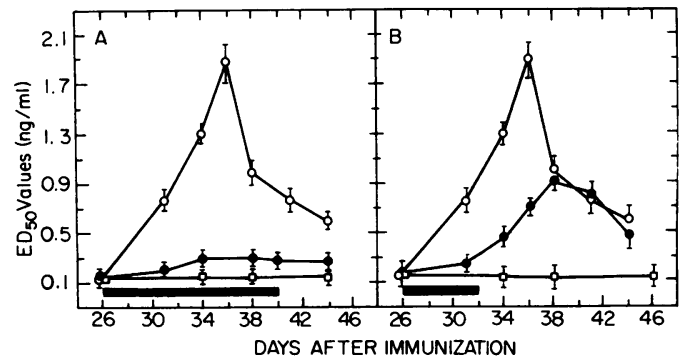

Figure 2. Isoproterenol treatment prevents fat cell desensitization. (A) Mice immunized to insulin received isoproterenol twice daily for $15 \mathrm{~d}$ (days 26-40, indicated by the bar). At the indicated time points fat cells were taken and examined for their lipogenic activity at increasing concentrations of insulin. Immunized mice receiving no isoproterenol (o); immunized mice receiving isoproterenol (๑); nonimmunized mice receiving isoproterenol $(\square)$. $(B)$ The same experimental design as in A, but a shorter duration of isoproterenol therapy (7 d, day 26-34) was used. Results are means \pm SD of a representative experiment. Each time point represents the $\mathrm{ED}_{50}$ value of pooled adipocytes obtained from five mice. 
Table I. Circulating Levels of Antiinsulin and Antireceptor Antibodies on Day 36 in Insulin Immunized Mice Receiving Isoproterenol

\begin{tabular}{|c|c|c|}
\hline & \multirow{2}{*}{$\begin{array}{l}\text { Antibodies to native } \\
\text { insulin }\end{array}$} & \multirow{3}{*}{$\begin{array}{c}\text { Receptor antibodies } \\
\text { Serum dilution to produce } \\
50 \% \text { of maximal } \\
\text { stimulation of lipogenesis }\end{array}$} \\
\hline & & \\
\hline & titer* & \\
\hline \multirow{2}{*}{$\begin{array}{l}\text { Immunized mice } \\
\text { Immunized mice plus } \\
\text { isoproterenol (days 28-40) }\end{array}$} & $10^{4}$ & $1.2 \pm 0.1 \times 10^{4}$ \\
\hline & $10^{4}$ & $1.2 \pm 0.12 \times 10^{4}$ \\
\hline
\end{tabular}

* Determined by A solid phase radioimmunoassay (35).

${ }^{\ddagger}$ Lipogenesis was performed in KRB buffer containing $0.2 \mathrm{mM}$ [U- ${ }^{14} \mathrm{C}$ ]glucose, $1 \%$ bovine serum albumin and about $2 \times 10^{5}$ rat adipocytes. Reaction was carried out for $90 \mathrm{~min}$ at $37^{\circ} \mathrm{C}$. Maximal lipogenesis obtained by incubation with $100 \mathrm{ng} / \mathrm{ml}$ of insulin was $340 \%$ of the basal lipogenesis (obtained in the absence of added hormone). Values are the means \pm SE of six mice. Each serum was measured for its antibody content individually.

could be observed after 7-8 $\mathrm{d}$ of treatment and persisted as long as this $\beta$-adrenergic agonist was administered (Fig. $2 A$ ). $\mathrm{ED}_{50}$ values of the insulin-immunized mice receiving isoproterenol were about twofold higher than the $\mathrm{ED}_{50}$ of control adipocytes (not shown) or those taken from control mice receiving isoproterenol (Fig. $2 A$ ).

Effect of isoproterenol is transient. In the experiments summarized in Fig. $2 B$, isoproterenol was administered for $7 \mathrm{~d}$ only (days 26-32 after immunization). The shorter duration was also effective (although to a lesser extent) in preventing fat cell desensitization to insulin (Fig. $2 B$ ). It is important to note that the effect of isoproterenol persisted 2-4 d after terminating treatment. Thus, cells obtained on days 34 to $36 \mathrm{had}$ much lower $\mathrm{ED}_{50}$ values than cells obtained from untreated immunized mice (Fig. $2 B$ ).

Administration of isoproterenol does not affect antireceptor antibodies. To investigate the possibility that isoproterenol prevented desensitization by decreasing the relevant antibodies, we measured the levels of both antiinsulin and receptor antibodies (Table I). No significant differences could be observed in the levels of either of these antibodies in immunized mice, as a result of isoproterenol administration (Table I). Thus, maintenance of the sensitivity of the fat cells to insulin was not due to a decrease in the level of the antibodies responsible for triggering desensitization.

Isoproterenol prevents refractoriness to insulin. In addition to desensitization, adipocytes taken from immunized mice exhibited considerably lower responsiveness to high $(100 \mathrm{ng} / \mathrm{ml})$ concentrations of insulin, a phenomenon termed refractoriness (18). The results shown in Fig. 1 and Table II demonstrate that the administration of isoproterenol in vivo also prevented refractoriness to insulin. Thus, the treatment inhibited the development of both desensitization and refractoriness.

Isoproterenol does not prevent receptor down regulation. In contrast to desensitization and refractoriness, the administration of isoproterenol in vivo could not block receptor down regulation (Table III). About 50\% of the sites were lost whether or not the immunized mice had received isoproterenol or were untreated. Thus, the mild degree of insensitivity to insulin demonstrate in treated mice (Figs. 1 and $2 A$ ) may be attributed predominantly to decreased receptor binding capacity. These results support the notion that down regulation and
Table II. Treatment with Isoproterenol Inhibits Receptor Refractoriness in Insulin Immunized Mice

\begin{tabular}{|c|c|c|c|}
\hline \multirow[b]{3}{*}{ Source of adipocytes } & \multicolumn{2}{|c|}{ Lipogenesis } & \multirow{3}{*}{$\begin{array}{c}\text { Percent } \\
\text { maximal } \\
\text { stimulation }\end{array}$} \\
\hline & \multicolumn{2}{|c|}{$\begin{array}{l}\text { cpm incorporated* } \\
\text { per } 3 \times 10^{5} \text { cells } / \mathrm{h}\end{array}$} & \\
\hline & No insulin & Insulin' & \\
\hline Control mice & $3,000 \pm 100$ & $7,200 \pm 200$ & 100 \\
\hline Immunized mice & $2,800 \pm 50$ & $4,500 \pm 100$ & 40.5 \\
\hline $\begin{array}{l}\text { Isoproterenol-treated } \\
\text { immunized mice' }\end{array}$ & $2,900 \pm 100$ & $6,700 \pm 150$ & 90.5 \\
\hline
\end{tabular}

* Lipogenesis was performed for $1 \mathrm{~h}$ at $37^{\circ} \mathrm{C}$.

${ }^{\ddagger}$ Hundred percent stimulation was taken as $V_{\text {ins }}-V_{\text {besal }}$ of the control group.

${ }^{8}$ Final concentration in the assay was $100 \mathrm{ng} \mathrm{ml}^{-1}$.

"Adipocytes were taken on day 36 after immunization. Each group contained adipocytes pooled from 5 mice.

'Adipocytes were taken on day 36 after immunization; treatment with isoproterenol began on day 26.

desensitization involve separate mechanisms and that desensitization does not occur as a result of receptor down regulation (16).

Administration of isoproterenol prevents fasting hyperglycemia. Because insulin resistance was accompanied by fasting hyperglycemia (2), we tested the effect of isoproterenol treatment on the concentration of blood glucose in fasting mice. Fig. 3 shows that, unlike the immunized mice, those receiving isoproterenol did not develop fasting hyperglycemia. This indicates that the fasting hyperglycemia seen in mice with antireceptor antibodies was due to desensitization and refractoriness, rather than to receptor down regulation.

Effects of $B_{1}$ receptor antagonists or aminophylline. To determine whether the effect of isoproterenol was mediated via $B_{1}$ receptor sites, isoproterenol was administered together with propranolol, a known $B_{1}$ antagonist (38). Propranolol, which by itself had no effect (Table IV), inhibited the effect of isoproterenol at a 10:1 molar ratio (Table IV). Metoprolol, a more specific $B_{1}$ antagonist (38) inhibited the effect of isoproterenol at a 3:1 molar ratio (Table IV). Thus the effect of isoproterenol seems to be mediated primarily by way of the $B_{1}$ subtype adrenergic receptor.

Table III. Treatment with Isoproterenol Does Not Inhibit Receptor Down Regulation

\begin{tabular}{lc}
\hline \multicolumn{1}{c}{ Source of adipocytes } & $\begin{array}{c}{\left[^{125} \text { I]Iodoinsulin }\right.} \\
\text { specifically bound }\end{array}$ \\
\hline & $f m o l / 10^{6} /$ cells \\
Control mice & $23 \pm 2$ \\
Immunized mice* & $11 \pm 1$ \\
Isoproterenol-treated immunized mice & $12 \pm 1$ \\
\hline
\end{tabular}

\footnotetext{
* Adipocytes were taken on day 36 after immunization to insulin. Each group contained adipocytes pooled from four mice. ${ }^{\ddagger}$ Binding was performed for $1 \mathrm{~h}$ at $22^{\circ} \mathrm{C}$ using $1 \mathrm{nM}\left[{ }^{125} \mathrm{I}\right]$ iodoinsulin, in the presence and the absence of $5 \mu \mathrm{M}$ unlabeled insulin.
} 


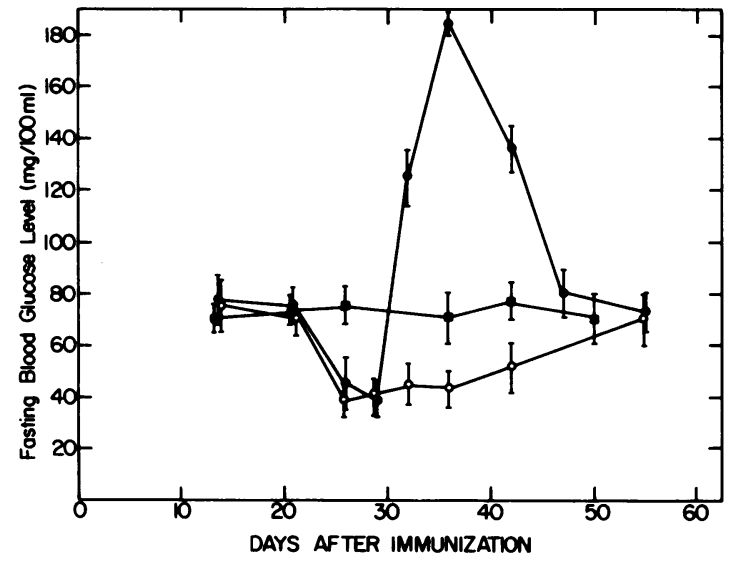

Figure 3. Administration of isoproterenol inhibits development of fasting hyerglycemia in insulin immunized mice. Fasting blood glucose levels were determined after removing food for $16 \mathrm{~h}$ (4 a.m.-8 p.m.) at the indicated time points in immunized mice receiving no isoproterenol (๑); in immunized mice receiving isoproterenol (0); and in nonimmunized mice receiving isoproterenol ( $\square$ ). Each group consisted of seven mice. Isoproterenol was administered for $15 \mathrm{~d}$ (days 25-40).

As the cAMP-phosphodiesterase inhibitor, aminophylline, can be absorbed orally (38), we evaluated its effect on desensitization and found that oral treatment of immunized mice for several days with aminophylline equally restored sensitization. Thus, developed desensitization can also be blocked by nonhormonal oral agents known to elevate cellular cAMP levels.

\section{Discussion}

Earlier studies from our laboratory revealed that mice immunized with ungulate insulins exhibit a critical and transitory period of 12-14 d (day 26-40 after primary immunization) during which antireceptor antibodies present in the circulation are associated with alterations in insulin receptor physiology and disturbances in glucose homeostatis (17-20). This study was done to establish conditions that might prevent the development of receptor-effector malfunction. Here, we report that administration of either a $\beta$-adrenergic agonist or aminophylline, prevented the development of fat cell desensitization and refractoriness (Figs. 1, $2 A$ and $B$, Tables II and IV). In contrast, the accompanying loss of insulin receptor sites (down regulation) was not inhibited (Table III). As the isoproterenol treatment eliminated fasting hyperglycemia (Fig. 3), the latter state can be attributed to postreceptor events (namely, desensitization and refractoriness), rather than to a loss of insulin binding capacity.

It is generally accepted that effects of $\beta$-adrenergic agonists are mediated through the production of cyclic AMP as a second messenger (39-41). This intracellular signal provides a general mechanism for protein phosphorylation catalyzed by the activation of CAMP-dependent protein kinases (39-41). It is also well documented that certain agents and/or conditions that elevate cAMP levels have an antagonistic influence on some insulin-responsive cellular enzyme systems, and vice versa. Examples are glycogen synthase and phosphorylase in muscle $(23,24)$, liver $(25,26)$, and adipocytes $(27,28)$, and hormone-sensitive lipase in adipocytes $(29,30)$. These antagonistic effects occur most likely at points distal to the production or de-esterification of the nucleotide itself, as insulin has been shown to either have no effect $(42-45)$ or even to increase $(46,47)$ cAMP levels in muscle or adipocytes, while still activating glycogen synthase in muscle $(47,48)$, or inhibiting lipolysis in adipocytes (42-45). In adipocytes, agents that elevate cAMP levels lead to an enhanced rate of lipolysis that can be inhibited by insulin. These, however, are rapid processes. Both initiation and termination occur within minutes after the addition or the removal of the respective hormones (42-45). In this study, however, the effect of isoproterenol persisted for 2-4 d after administration was terminated (Fig. $2 \mathrm{~B}$ ). Therefore, it is conceivable that the effect might be mediated by a modification of longer duration, such as might be attributed to protein synthesis. In cultured cells insulin stimulates protein synthesis (49) and inhibits protein degradation (50). Insulin may regulate rates of transcription and translation and may have either positive (51) or negative (52) effects on the levels of

Table IV. Effect of Various Agents in Restoring Fat Cell Desensitization of Immunized Mice In Vivo

\begin{tabular}{|c|c|c|c|c|}
\hline Group of mice & Type of treatment & Class of agent & $\begin{array}{l}\text { ED }_{\text {so values* }} \\
\text { (day 36) }\end{array}$ & $\begin{array}{c}\left(\mathrm{ED}_{\mathbf{s 0}} \text { control/ED }\right. \\
\times 100\end{array}$ \\
\hline & & & $n g / m l$ & \\
\hline Control & None & - & $0.15 \pm 0.02$ & 100 \\
\hline Immunized $^{\ddagger}$ & None & - & $2.0 \pm 0.3$ & 7.5 \\
\hline Immunized & Isoproterenol $(30 \mu \mathrm{g} / \mathrm{d})^{\S}$ & $\beta$-agonist & $0.35 \pm 0.05$ & 42 \\
\hline Immunized & Propranolol $(300 \mu \mathrm{g} / \mathrm{d})$ & $\beta$-antagonist & $1.9 \pm 0.2$ & 7.8 \\
\hline Immunized & Isoproterenol + propanolol $(300 \mu \mathrm{g} / \mathrm{d})$ & $\beta$-agonist $+\beta$-antagonist & $2.0 \pm 0.3$ & 7.5 \\
\hline Immunized & Isoproterenol + metoprolol $(50 \mu \mathrm{g} / \mathrm{d})$ & $\beta$-agonist $+\beta_{1}$-antagonist & $1.3 \pm 0.2$ & 11.5 \\
\hline Immunized & Isoproterenol + metoprolol $(100 \mu \mathrm{g} / \mathrm{d})$ & $\beta$-agonist $+\beta_{1}$-antagonist & $2.2 \pm 0.3$ & 6.8 \\
\hline Immunized & Aminophylline $(1 \mathrm{~g} / \mathrm{d})^{\prime \prime}$ & PDE inhibitor & $0.36 \pm 0.03$ & 42 \\
\hline
\end{tabular}

* Determined by the assay of lipogenesis. ${ }^{\ddagger}$ Mice were immunized by inoculating each hind footpad with $25 \mu \mathrm{g}$ of bovine insulin emulsified in complete Freund's adjuvant (according to reference 19). Each group consisted of 7-10 mice. Administered twice daily at 8 a.m. and 3 p.m. Isoproterenol was administered at $30 \mu \mathrm{g} / \mathrm{d}$ in all experiments summarized in the table. "Administered orally, twice daily $1 \mathrm{mg} / \mathrm{d}$ using a soft rubber catheter. 
specific mRNA synthesis. With respect to translational control, insulin and growth factors on the one hand and hormones that elevate levels of intracellular cAMP on the other, may initiate cellular events that ultimately result in the phosphorylation of ribosomal protein S6 (reviewed in 53). Thus, antagonistic actions of insulin to hormones known to elevate cAMP levels may also exist on the regulatory level of protein synthesis and protein degradation.

Further studies in vitro are required in order to elucidate the molecular mechanisms involved in insulin desensitization and its prevention by $\beta$-adrenergic stimulation. Care, however, should be taken in choosing a suitable in vitro system, as more than one mechanism can lead to desensitization. In rat hepatoma cells, for example, insulin causes desensitization to the induction of tyrosine aminotransferase by IGF-I and IGF-II, which mediate this activity via their own distinct receptor sites (54). Thus, desensitization in this cell type may be distal to the insulin receptor itself. Also, studies of insulin desensitization in cultured cells are usually applied to the intermediate and the long-term actions of insulin. These types of desensitization may not necessarily coincide with desensitization of the immediate, or short-term actions of insulin, such as the stimulation of glucose uptake and its metabolism.

Several studies have demonstrated a partial reduction in insulin binding and/or in stimulating hexose uptake as a result of $\beta$-adrenergic stimulation in in vitro systems. These effects are presumably mediated via cAMP (55-58) and are shown to be both rapid and transient, namely they proceed and are reversed within minutes after the addition or the removal of isoproterenol (55). The effects observed in our study seem to involve synchronous cAMP-dependent events, which induce alterations of longer duration (Fig. 1). A link, however, between these two cAMP-dependent actions is conceivable and is currently being studied.

However, the clinical application of our observations need not await a complete biochemical characterization; $\beta$-adrenergic agonists are widely and safely used. Aminophylline and related methyl-xanthines can be administered orally. These agents are now thought to increase cAMP levels primarily by virtue of their interaction with adenosine receptors (59). This can result from displacement of adenosine from inhibiting receptors or from direct activation of stimulatory adenosine receptors (59). Our results suggest that these agents could be tried to treat patients suffering from insulin resistance. The most striking insulin resistance is demonstrable in patients suffering from type B acantosis nigricance with antiinsulin receptor antibodies, usually of the IgG type (60). However, we have observed that antiinsulin receptor antibodies of the IgM type are found in patients with type I diabetes (61), where a mild resistance to insulin is often present (62). Insulin resistance is the hallmark of type II diabetes (6), which may also have an autoimmune component. Thus, agents that could prevent or reverse antibody-mediated receptor desensitization might be of value. The results presented here in addition indicate that the pathological significance of autoantibodies to hormone receptors is influenced greatly by how the endocrine system reads and implements the signals transmitted by the antibodies. As shown in Fig. 3, preventing adaptive desensitization led to prolonged hypoglycemia in place of hyperglycemia in the immunized mice. Indeed, we have observed persis- tent hypoglycemia in a child with antireceptor antibodies of the same antiidiotypic specificity as the mouse antibodies apparently responsible for receptor desensitization and hyperglycemia (63). Thus, the insulin receptor of certain individuals may respond to anti-receptor antibodies without undergoing adaptive desensitization.

\section{Acknowledgments}

We thank Jeffrey Gerst for major revision and Batia Zarmi and Dr. Menachem Shefi from Sheba Medical Center for technical assistance.

This research was supported in part by the Fund for Basic Research, administered by the Israel Academy of Sciences and Humanities (to Dr. Shechter) and a grant from the Juvenile Diabetes Foundation (to Dr. Cohen and Dr. Shechter), Dr. Shechter is the incumbent of the C. H. Hollenberg Chair in Metabolic and Diabetes Research established by the Friends and Associates of Dr. C. H. Hollenberg of Toronto, Canada, and Dr. Cohen is the incumbent of the Mauerberger Professorial Chair in Immunology.

\section{References}

1. Kahn, C. R., K. Megyesi, R. S. Bar, R. C. Eastman, and J. S. Flier. 1977. Receptors for peptide hormones. Ann. Intern. Med. 86:205-219.

2. Pollet, R. J., and G. S. Levey. 1980. Insulin inhibition of protein degradation in cell monolayers. Ann. Intern. Med. 92:663-680.

3. Kosmakos, F. C., and J. Roth. 1980. Insulin-induced loss of the insulin receptor in IM-9 lymphocytes. A biological process mediated through the insulin receptor. J. Biol. Chem. 255:9860-9869.

4. Olefsky, J. M., and H. G. Kolterman. 1981. Mechanism of insulin resistance in obesity and noninsulin-dependent (type II) diabetes. Am. J. Med. 70:151-168.

5. Soll, A. H., C. R. Kahn, and D. M. Neville, Jr. 1975. Insulin binding to liver plasma membranes in the obese hyperglycemic (ob/ob) mouse. Demonstration of a decreased number of functionally normal receptors. J. Biol. Chem. 250:4702-4707.

6. Gavin, J. R., III, J. Roth, D. M. Neville, Jr., P. DeMeyts, and D. N. Buell. 1974. Insulin dependent regulation of insulin receptor concentrations: A direct demonstration in cell culture. Proc. Natl. Acad. Sci. USA. 71:84-88.

7. Baldwin, D., M. Prince, S. Marshall, P. Davies, and J. M. Olefsky. 1980. Regulation of insulin receptors: evidence for involvement of an endocytotic internalization pathway. Proc. Natl. Acad. Sci. USA. 77:5975-5978.

8. Mott, D. M., B. V. Howard, and P. H. Bennett. 1979. Stoichiometric binding and regulation of insulin receptors on human diploid fibroblasts using physiologic insulin levels. J. Biol. Chem. 254:87628767.

9. Livinston, J. N., B. J. Purvis, and D. H. Lockwood. 1978. Insulin induced changes in insulin binding and insulin sensitivity of adipocytes. Metab. Clin. Exp. 27:2009-2014.

10. Marshall, S., and J. M. Olefsky. 1980. Effects of insulin incubation on insulin binding, glucose transport, and insulin degradation by isolated rat adipocytes. Evidence for hormone induces desensitization at the receptor and postreceptor level. J. Clin. Invest. 66:763-772.

11. Peterson, B., S. Beckner, and M. Blecher. 1978. Characterization of insulin receptors in a new line of cloned neonatal rat hepatocytes. Biochim. Biophys. Acta. 542:470-485.

12. Blackard, W. G., P. S. Guzelian, and M. E. Small. 1978. Down regulation of insulin receptors in primary cultures of adult rat hepatocytes in monolayer. Endocrinology. 103:548-553.

13. Caro, J. F., and J. M. Amatruda. 1980. Insulin receptors in hepatocytes: Post receptor events mediated down regulation. Science (Wash. DC). 210:1029-1031. 
14. Shechter, Y. 1985. Studies on insulin receptors: Implications for insulin action. In The Receptors. Vol. II. M. P. Conn, editor. Academic Press, Orlando, FL. 221-244.

15. Martin, M. S., and S. L. Pohl. 1979. Insulin-induced insulin resistance of $\alpha$ amine isobutyric acid transport in cultured human skin fibroblast. J. Biol. Chem. 256:12257-12262.

16. Heaton, J. H., and T. D. Gelehrter. 1981. Desensitization of hepatoma cells to insulin action. Evidence for a post receptor mechanism. J. Biol. Chem. 256:12257-12262.

17. Shechter, Y., D. Elias, R. Maron, and I. R. Cohen. 1984. Mouse antibodies to the insulin receptor developing spontaneously as antiidiotypes. I. Characterization of the antibodies. J. Biol. Chem. 259:6411-6415.

18. Elias, D., R. Maron, I. R. Cohen, and Y. Shechter. 1984. Mouse antibodies to the insulin receptor developing spontaneously as antiidiotypes. II. Effects on glucose homeostasis and the insulin receptor. $J$. Biol. Chem. 259:6416-6419.

19. Shechter, Y., R. Maron, D. Elias, and I. R. Cohen. 1982. Autoantibodies to insulin spontaneously develop as anti-idiotypes in mice immunized with insulin. Science (Wash. DC). 216:542-545.

20. Shechter, Y., D. Elias, R. Maron, and I. R. Cohen. 1983. Mice immunized to insulin develop antibodies to the insulin receptor. $J$. Cell. Biochem. 21:179-185.

21. Czech, M. P. 1977. Molecular basis of insulin action. Annu. Rev. Biochem. 46:359-384.

22. Czech, M. P. 1985. Molecular basis of insulin action. Annu. Rev. Physiol. 47:357-381.

23. Larner, J., C. Villar-Palasi, N. D. Goldberg, J. S. Bishop, F. Huijing, J. I. Wenger, H. Sasko, and N. E. Brown. 1968. In Control of Glycogen Metabolism. W. J. Whelan, editor. Academic Press, London.

24. Schlender, K. K., S. H. Wei, and C. Villar-Palasi. 1969. UDPglucose: Glycogen $\alpha 4$ glycosyltransferase I kinase activity of purified muscle protein kinase. Cyclic nucleotide specificity. Biochim. Biophys. Acta. 191:272-278.

25. Bishop, J. S., and J. Larner. 1969. Presence in liver of a 3':5'cyclic AMP stimulated kinase for the form of UDPG-glycogen glycosyltransferase. Biochim. Biophys. Acta. 171:374-377.

26. Sutherland, E. W., and G. A. Robinson. 1966. Metabolic effects of catecholamines. The role of cyclic-3',5' AMP in response to catecholamines and other hormones. Pharmacol. Rev. 18:145-161.

27. Miller, E., B. Fredholm, R. E. Miller, D. Steinberg, and S. E. Mayer. 1975. Enzymes regulating glycogen metabolism in swine subcutaneous adipose tissue. I. Phosphorylase and phosphorylase phosphatase. Biochemistry. 14:2470-2480.

28. Miller, R. E., E. A. Miller, B. Fredholm, J. B. Yellin, R. D. Eichner, S. E. Mayer, and D. Steinberg. 1975. Enzymes regulating glycogen metabolism in swine subcutaneous adipose tissue. II. Glycogen synthase. Biochemistry. 14:2481-2488.

29. Corbin, J. D., E. M. Reimann, D. A. Walsh, and E. G. Krebs. 1970. Activation of adipose tissue lipase by skeletal muscle cyclic adenosine 3',5'-monophosphate stimulated protein kinase. J. Biol. Chem. 245:4849-4851.

30. Khoo, J. C., A. A. Aquino, and D. Steinberg. 1974. The mechanism of activation of hormone sensitive lipase in human adipose tissue. J. Clin. Invest. 53:1124-1131.

31. Rodbell, M. 1964. Metabolism of isolated fat cells. J. Biol. Chem. 239:375-380.

32. Hunter, W. M., and F. C. Greenwood. 1962. Preparation of iodine-131 labeled human growth hormone of high specific activity. Nature (Lond.). 194:495-496.

33. Gliemann, J., K. Osterland, J. Vinten, and S. Gammeltoft. 1972. A procedure for measurement of distribution spaces in isolated fat cells. Biochim. Biophys. Acta. 286:1-9.

34. Moody, F. A. J., M. A. Stan, M. Stan, and J. Gliemann. 1974. A simple free fat cell bioassay for insulin. Horm. Metab. Res. 6:12-16.

35. Eshhar, Z., G. Strassmann, T. Waks, and E. Mozes. 1979. In vitro and in vivo induction of effector $T$ cells mediating other responses to a protein and a synthetic polypeptide antigen. Cell. Immunol. 47:378-389.

36. Minneman, K. P., R. N. Pittman, and P. B. Molinoff. 1981. $\beta$ Adrenergic receptor subtypes. Properties, distribution, and regulation. Annu. Rev. Neurosci. 4:419-461.

37. Dugan, K. W., Y. W. Cho, A. W. Gomoll, D. M. Aviado, and P. M. Lish. 1968. Pharmacologic potency and selectivity of a new bronchodilator agent: SOTERENOL (MJ 1992) J. Pharmacol. Exp. Ther. 164:290-301.

38. Gilman, G. A., L. S. Goodman, T. W. Rall, and F. Murad. 1986. In The Pharmacological Basis of Therapeutics. 7th Ed. Macmillan Publishing Co., New York. 192-194, 589-600.

39. Sutherland, E. W., I. Oye, and R. W. Butcher. 1965. The action of epinephrine and the role of the adenyl cyclase system in hormone action. Recent Prog. Horm. Res. 21:623-646.

40. Robinson, G. A., R. W. Butcher, and E. W. Sutherland. 1971. Cyclic AMP. Academic Press, New York.

41. Hittelman, K. J., and R. W. Butcher. 1972. In Effects of Drugs on Cellular Control Mechanisms. B. R. Rabin, and R. B. Freedman, editors. Macmillan Press Ltd., London.

42. Jarett, L., A. L. Steiner, R. M. Smith, and D. M. Kipnis. 1972. The involvement of cyclic AMP in the hormonal regulation of protein synthesis in rat adipocytes. Endocrinology. 90:1277-1284.

43. Fain, J. N., and L. Rosenberg. 1972. Antilipolytic action of insulin in fat cells. Diabetes. 21(Suppl. 2):414-425.

44. Siddle, K., and C. N. Hales. 1974. The relationship between the concentration of adenosine $3^{\prime} ; 5^{\prime}$-cyclic monophosphate and the antilipolytic action of insulin in isolated rat fat cells. Biochem. J. 142:97103.

45. Fain, J. N. 1971. Effects of menadione and vitamin $K_{5}$ on glucose metabolism, respiration, lipolysis, cyclic 3',5'-adenylic acid accumulation, and adenyl cyclase in white fat cells. Mol. Pharmacol. 7:465-479.

46. Goldberg, N. D., C. Villar-Palasi, H. Sasko, and J. Larner. 1967. Effects of insulin treatment on muscle 3',5'-cyclic adenylate levels in vivo and in vitro. Biochim. Biophys. Acta. 148:665-672.

47. Fain, J. N. 1975. Insulin as an activator of cyclic AMP accumulation in rat fat cells. J. Cyclic Nucleotide Res. 1:359-366.

48. Craig, J. W., T. W. Rall, and J. Larner. 1969. The influence of insulin and epinephrine on adenosine 3',5'-phosphate and glycogen transferase in muscle. Biochim. Biophys. Acta. 177:213-219.

49. Hershko, A., P. Mamont, R. Shields, and G. M. Tomkins. 1971. Pleiotypic response. Nat. New Biol. 232:206-211.

50. Ballard, F. J., S. S. C. Wong, S. E. Knowles, N. C. Partridge, T. J. Martin, C. M. Wood, and J. M. Gunn. 1980. Insulin inhibition of protein degradation in cell monolayers. J. Cell. Physiol. 105:335-346.

51. Peavey, D. E., J. M. Taylor, and L. S. Jefferson. 1978. Correlation of albumin production rates and albumin mRNA levels in livers of normal, diabetic, and insulin treated diabetic rats. Proc. Natl. Acad. Sci. USA. 75:5879-5883.

52. Cimbala, M. A., W. H. Lamers, K. Nelson, J. E. Monahan, H. Yoo-Waren, and R. W. Hanson. 1982. Rapid changes in the concentration of phosphoenolpyruvate carboxykinase mRNA in rat liver and kidney. J. Biol. Chem. 257:7629-7636.

53. Strauss, D. S. 1984. Growth stimulatory action of insulin in vitro and in vivo. Endocrine Rev. 5:356-369.

54. Heaton, J. H., N. L. Krett, J. M. Alvarez, T. D. Gelehrter, J. A. Romanus, and M. M. Rechler. 1984. Insulin regulation of insulin-like growth factor action in rat hepatoma cells. J. Biol. Chem. 259:23962402.

55. Pessin, E. J., W. Gitomer, Y. Oka, C.-L. Openheimer, and M. P. Czech. 1983. $\beta$-adrenergic regulation of insulin and epidermal growth factor receptors in rat adipocytes. J. Biol. Chem. 258:73867394.

56. Green, A. 1983. Catecolamines inhibit insulin-stimulated glu- 
cose transport in adipocytes, in the presence of adenosine deaminase. FBS (Fed. Eur. Biochem. Soc.) Lett. 152:261-264.

57. Smith, U., M. Kuroda, and I. A. Simpson. 1984. Counter-regulation of insulin-stimulated glucose transport by catecholamines in the isolated rat adipose cell. J. Biol. Chem. 259:8758-8763.

58. Häring, H., D. Kirch, B. Obermaier, B. Ermel, and F. Machicao. 1986. Decreased tyrosine kinase activity of insulin receptor isolated form rat adipocytes rendered insulin-resistant by catecholamines treatment. Biochem. J. 234:59-66.

59. Wells, J. N. and G. L. Kramer. 1981. Phosphodiesterase inhibitors as tools in cyclic nucleotide research: a precautionary comment. Mol. Cell. Endocrinol. 23:1-9.

60. Grunfeld, C., E. Van Obberghen, F. A. Karlsson, and C. R.
Kahn. 1980. Antibody-induced desensitization of the insulin receptor. Studies of the mechanism of desensitization in 3T3-L1 fatty fibroblasts. J. Clin. Invest. 66:1124-1134.

61. Maron, R., D. Elias, B. M. de Jongh, G. J. Bruining, J. J. Van Rood, Y. Shechter, and I. R. Cohen. 1983. Autoantibodies to the insulin receptor in juvenile onset insulin-dependent diabetes. Nature (Lond.). 303:817-818.

62. Kahn, C. R. 1986. Insulin resistance: A common feature of Diabetes Mellitus. N. Engl. J. Med. 315:252-253.

63. Elias, D., I. R. Cohen, Y. Shechter, Z. Spirer, and A. Golander. 1987. Antibodies to insulin receptor followed by anti-idiotype antibodies to insulin in child with hypoglycemia. Diabetes. 36:348-354. 